\title{
Relación valina:lisina digestible en la dieta de pollos de engorda
}

\author{
Digestible valine-to-lysine ratio in diets for broiler \\ chickens
}

\author{
Alexandra Potençaa, Alice Eiko Murakamib, Iván Camilo Ospina-Rojasc, \\ Jovanir Inês Muller Fernandesd
}

\begin{abstract}
RESUMEN
El objetivo fue evaluar el efecto de la relación valina:lisina digestible (Val:Lys dig) en la dieta de pollos de engorda en el período de 1 a 14 días de edad sobre el comportamiento productivo, emplume, diámetro y perfil de fibras musculares. Se utilizaron 1,800 pollos de engorda Cobb de un día de edad, distribuidos en un diseño experimental completamente al azar con cinco tratamientos, seis repeticiones y 36 aves por unidad experimental. Los tratamientos consistieron de diferentes relaciones de Val:Lys dig (66, 71, 76, 81 y 86 \%). La relación Val:Lys dig no afectó $(P>0.05)$ el comportamiento productivo de las aves. Sin embargo, hubo efecto lineal positivo $(P<0.05)$ de la relación Val:Lys dig en la longitud de las plumas del dorso y en la puntuación de emplume del muslo y pechuga. La relación Val:Lys dig resultó en efecto cuadrático $(P<0.05)$ sobre el diámetro de las fibras musculares, siendo estimada una relación de $76 \%$ de Val:Lys dig. El perfil de las fibras musculares no se afectó $(P>0.05)$ por los tratamientos. Se concluye que la relación Val:Lys de $66 \%$ es suficiente para maximizar el comportamiento productivo de pollos de engorda en la fase de 1 a 14 días, no obstante, una mayor relación de Val:Lys dig (76 \%) es necesaria para maximizar el crecimiento de las fibras musculares.
\end{abstract}

PALABRAS CLAVE: Aminoácido digestible, Aminoácido de cadena ramificada, Fibra muscular.

\begin{abstract}
This study was developed to evaluate the effect of the digestible valine:lysine ratio (dig Val:Lys) in the diet of 1 to 14-d-old broilers on performance, feathering, diameter and profile of muscle fibers. A total of 1,080 1-dold Cobb 500 broilers were distributed in a completely randomized experimental design with five treatments and six replicates of 36 birds each. Treatments consisted of different dietary ratios of dig Val:Lys (66, 71, 76, 81 and $86 \%)$ in the period between 1 and $14 \mathrm{~d}$ of age. The dig Val:Lys ratio did not influence $(P>0.05)$ bird performance. Nevertheless, there was a positive linear effect $(P<0.05)$ of dig Val:Lys ratio on back feather length and feathering score of the thigh and breast. The dig Val:Lys ratio had a quadratic effect $(P<0.05)$ on the diameter of muscle fibers, with an estimated dig Val:Lys ratio of $76 \%$. The muscle fiber profile was not influenced $(P>0.05)$ by the treatments. It was concluded that a Val:Lys ratio of $66 \%$ is sufficient to maximize the performance of broilers from 1 to $14 \mathrm{~d}$ of age; however, a higher dig Val:Lys ratio (76 \%) is needed to maximize muscle fiber growth.
\end{abstract}

KEY WORDS: Digestible amino acid, Branched-chain amino acid, Muscle fiber.

\section{INTRODUCCIÓN}

Los aminoácidos son nutrientes esenciales para las aves y representan una gran proporción de

\section{INTRODUCTION}

Amino acids are essential nutrients for birds and represent a large share of feed formulation

\footnotetext{
Recibido el 22 de octubre de 2013. Aceptado el 5 de febrero de 2014

a Departamento de Zootecnia, Universidade Federal de Mato Grosso (UFMT), Cuiabá - Brasil.

b Departamento de Zootecnia, Universidade Estadual de Maringá (UEM), Maringá - Brasil.

c Programa de Pós-graduação em Zootecnia, Universidade Estadual de Maringá (UEM), Maringá - Brasil. icospinarojas@gmail.com. Correspondencia al tercer autor.

d Departamento de Medicina Veterinária, Universidade Federal do Paraná (UFPR), Palotina - Brasil.
} 
los costos en la formulación de raciones, con un impacto directo sobre el desempeño animal. Debido a la fuerte presión internacional, se ha vuelto casi imposible el usar ingredientes de origen animal como fuente de aminoácidos. Por lo tanto, el uso de la soja y sus derivados se han afianzado en la formulación de dietas. Sin embargo, ingredientes de origen vegetal tienen un valor inferior de aminoácidos en comparación con las fuentes de origen animal(1).

La proteína del maíz es proporcionalmente mayor en leucina (Leu) que en valina (Val) e isoleucina (Ile), con valores de $1.01,0.40 \mathrm{y}$ $0.29 \%$, respectivamente $(2)$. Alto contenido de Leu en las dietas aumenta las necesidades de Val e Ile en pollos y pavos(3). Val es uno de los aminoácidos esenciales necesarios para el crecimiento y mantenimiento del tejido y junto a Leu e Ile pertenece al grupo de los aminoácidos de cadena ramificada (AACR), un nombre derivado de su estructura molecular.

Las líneas de pollos de engorda con crecimiento inicial más rápido, como Cobb, son ampliamente utilizadas, pero poco se sabe sobre sus necesidades de Val. Como la "carne" corresponde a los músculos esqueléticos de las aves, los estudios de crecimiento deben evaluar cambios en la composición del músculo, dado que el crecimiento de los animales se acompaña de cambios en el tamaño y la proporción de fibras musculares(4).

Siguiendo el desarrollo embrionario, el crecimiento de las fibras musculares se produce sólo por medio de hipertrofia; este incremento en el diámetro de la fibra muscular es principalmente el resultado de la deposición de proteína miofibrilar (actina y miosina)(4). Los principales aminoácidos que componen estas proteínas son aminoácidos $A A C R$, incluyendo la Val(5).

La musculatura esquelética de las aves se compone de fibras musculares rojas (de lenta oxidación), blancas (rápidas glicolíticas) y fibras intermedias (rápidas oxidativo glicolíticas)(6). Val costs, with a direct impact on animal performance. Due to strong international pressure, it has become impossible to use animal-based ingredients as sources of amino acids. Therefore, the use of soybean and its byproducts has gained a foothold in feed formulas. However, vegetable-based ingredients have an inferior amino acid balance compared to animal sources(1).

Corn protein is disproportionately higher in leucine (Leu) than in valine (Val) and isoleucine (Ile), containing values of $1.01,0.40$ and $0.29 \%$, respectively(2). High Leu content in the diets increases Val and Ile needs in chickens and turkeys (3). Val is one of the essential amino acids necessary for tissue maintenance and growth, and along with Leu and Ile belongs to the branched-chain amino acids (BCAA) group, a name derived from to their molecular structure.

Broiler lines with faster early growth, such as Cobb, are widely used, but little is known about Val needs in these birds. As "meat" corresponds to the skeletal muscles of birds, studies on growth must evaluate changes in muscle composition, given that animal growth is accompanied by changes in the size and ratio of muscle fibers( 4 ).

Following embryonic development, the growth of muscle fibers occurs only through hypertrophy; this increase in muscle fiber diameter results mainly from the deposition of myofibrillar protein (actin and myosin)(4). The main amino acids that make up these proteins are $B C A A$, including $\mathrm{Val}(5)$.

The skeletal musculature of birds comprises red muscle fibers (slow oxidative), white fibers (fast glycolytic) and intermediate fibers (fast oxidative glycolytic)(6). Val can act on the different types of muscle fiber, whereas lysine (Lys) acts specifically on white fibers, which are particularly prevalent in the breast of broilers $(7)$.

Broiler producers have shown concern over financial losses caused by slaughter line losses 
puede actuar sobre los diferentes tipos de fibra muscular, mientras que la lisina (Lys) actúa específicamente sobre fibras blancas, que son particularmente frecuentes en la pechuga de pollos de engorda(7).

Los productores de pollo han mostrado preocupación por los prejuicios financieros causados por pérdidas en la línea de matanza debido a laceraciones de la canal. Un aumento en las lesiones de piel puede atribuirse al inadecuado desplume, que se ha vuelto cada vez más común en parvadas.

Las plumas son estructuras con queratina, formadas por varios aminoácidos, incluyendo AACR, y sirven para cubrir el cuerpo de las aves y protegerlas contra la intemperie, así como ayudar con la termorregulación del cuerpo(8). Cualquier desequilibrio de AACR en la dieta conduce a plumas anormales en forma cóncava, que se doblan hacia fuera del cuerpo del ave. Esto está ligado generalmente con bajas de peso y pobre conversión alimenticia(9).

Basándose en esta información, el objetivo del trabajo fue evaluar el efecto de la relación de valina:lisina digestible (Val:Lys dig) en alimentos para pollos de engorda Cobb 500 entre 1 y 14 días de edad, en el rendimiento, emplume, rendimiento de la canal, y diámetro y composición de las fibras del músculo flexor hallucis longus.

\section{MATERIALES Y METODOS}

Se utilizó un total de 1,080 pollitos machos Cobb 500 de un día de edad, con un promedio de $43.30 \mathrm{~g}$ y vacunados contra la enfermedad de Marek en el criadero. El diseño experimental fue completamente al azar, con cinco tratamientos y seis repeticiones de 36 aves cada uno. Los tratamientos consistieron en relaciones de Val:Lys dig porcentual $(66,71,76,81$ y $86 \%)$ en el periodo de 1 a 14 días de edad. El maíz y la harina de soya en el alimento se formularon según los valores de la composición química de los alimentos y necesidades nutricionales from carcass lacerations. An increase in skin lesions can be attributed to poor bird feathering, which has become increasingly common in poultry flocks.

Feathers are keratinized structures formed by several amino acids, including BCAA, and serve to cover the body of birds and protect them against the elements and help with body thermoregulation(8). Any BCAA imbalance in the diet leads to abnormal concave-shaped feathers, which bend outwards from the bird's body. This is usually linked to lower weight and poor feed conversion(9).

Based on this information, the objective was to evaluate the effect of the digestible valine:lysine ratio (dig Val:Lys) in feeds for Cobb 500 broilers between 1 and $14 \mathrm{~d}$ of age on performance, feathering, carcass yield, diameter and composition of fibers in the flexor hallucis longus muscle.

\section{MATERIALS AND METHODS}

A total of 1,080 1-d-old male Cobb 500 broiler chicks were used, averaging $43.30 \mathrm{~g}$ and vaccinated against Marek's disease in the hatchery. The experimental design was entirely randomized, with five treatments and six replicates of 36 birds each. Treatments consisted of 5 dig Val:Lys ratios $(66,71,76,81$ and $86 \%)$ from 1 to $14 \mathrm{~d}$ of age. The corn and soybean meal-based feeds were formulated according to chemical composition values of the feeds and nutritional needs recommended by Rostagno et al(10), with the exception of dig Val levels (Table 1). Between 15 and $42 \mathrm{~d}$ of age, the same ratios of dig Val:Lys as supplied from 1 to $14 \mathrm{~d}$ of age were maintained; however, diet levels were altered to meet the nutritional needs for average performance birds during the growth and final phases(10).

The birds were housed in a regular $30 \times 8 \mathrm{~m}$ shed, divided into $5.2 \mathrm{~m}^{2}$ pens, covered by a cement tile roof, with concrete floors and $0.4 \mathrm{~m}$ tall brick side walls, complemented with chicken 
Cuadro 1. Composición porcentual y calculada de las dietas experimentales para pollos de 1 a 14 días de edad

Table 1. Percent and calculated composition of the experimental diets for 1 to 14-d-old broilers

\begin{tabular}{|c|c|c|c|c|c|}
\hline \multirow[b]{2}{*}{ Ingredients } & \multicolumn{5}{|c|}{ Digestible valine:lysine ratio } \\
\hline & 66 & 71 & 76 & 81 & 86 \\
\hline Corn & 55.80 & 55.80 & 55.80 & 55.80 & 55.80 \\
\hline Soybean meal, $45 \%$ & 36.50 & 36.50 & 36.50 & 36.50 & 36.50 \\
\hline Soybean oil & 2.50 & 2.50 & 2.50 & 2.50 & 2.50 \\
\hline Limestone & 0.96 & 0.96 & 0.96 & 0.96 & 0.96 \\
\hline Dicalcium phosphate & 1.95 & 1.95 & 1.95 & 1.95 & 1.95 \\
\hline Sodium bicarbonate & 0.34 & 0.34 & 0.34 & 0.34 & 0.34 \\
\hline Salt & 0.30 & 0.30 & 0.30 & 0.30 & 0.30 \\
\hline DL-Met 99\% & 0.39 & 0.39 & 0.39 & 0.39 & 0.39 \\
\hline L-Lys HCL 78.5\% & 0.41 & 0.41 & 0.41 & 0.41 & 0.41 \\
\hline L-Thr $98 \%$ & 0.18 & 0.18 & 0.18 & 0.18 & 0.18 \\
\hline L-Val $98 \%$ & 0.00 & 0.07 & 0.14 & 0.20 & 0.27 \\
\hline Vitamin and mineral suppl.* & 0.15 & 0.15 & 0.15 & 0.15 & 0.15 \\
\hline Inert $(\text { Kaolin })^{* \star}$ & 0.48 & 0.41 & 0.34 & 0.27 & 0.20 \\
\hline $\mathrm{BHT}$ & 0.05 & 0.05 & 0.05 & 0.05 & 0.05 \\
\hline Total & 100 & 100 & 100 & 100 & 100 \\
\hline \multicolumn{6}{|l|}{ Calculated values (\%): } \\
\hline Crude protein & 21.87 & 21.87 & 21.87 & 21.87 & 21.87 \\
\hline $\mathrm{ME}, \mathrm{kcal} / \mathrm{kg}$ & 2.959 & 2.959 & 2.959 & 2.959 & 2.959 \\
\hline Calcium & 0.950 & 0.950 & 0.950 & 0.950 & 0.950 \\
\hline Available phosphorus & 0.470 & 0.470 & 0.470 & 0.470 & 0.470 \\
\hline Sodium & 0.185 & 0.185 & 0.185 & 0.185 & 0.185 \\
\hline Chloride & 0.046 & 0.046 & 0.046 & 0.046 & 0.046 \\
\hline Potassium & 0.824 & 0.824 & 0.824 & 0.824 & 0.824 \\
\hline Met + dig Cys & 0.970 & 0.970 & 0.970 & 0.970 & 0.970 \\
\hline Dig Lys & 1.360 & 1.360 & 1.360 & 1.360 & 1.360 \\
\hline Dig Trp & 0.240 & 0.240 & 0.240 & 0.240 & 0.240 \\
\hline Dig Val & 0.900 & 0.968 & 1.036 & 1.104 & 1.173 \\
\hline Dig lle & 0.846 & 0.846 & 0.846 & 0.846 & 0.846 \\
\hline Dig Leu & 1.720 & 1.720 & 1.720 & 1.720 & 1.720 \\
\hline Dig Thr & 0.720 & 0.720 & 0.720 & 0.720 & 0.720 \\
\hline Dig Arg & 1.370 & 1.370 & 1.370 & 1.370 & 1.370 \\
\hline BED (Na+K" Cl), mEq/kg & 206 & 206 & 206 & 206 & 206 \\
\hline
\end{tabular}

*Vitamin and mineral supplement (Content per kg of premix): Vit. A 7,000,000 IU; Vit. D3 2,200,000 IU; Vit. E 11,000 mg; Vit. K3 1,600 mg; Vit. B1 2,000 mg; Vit. B2 5,000 mg, Vit. B12 12,000 $\mu$ g; Vit. B6 3,000 mg, Niacin 35,000 mg; Pantothenic acid 13,000 mg; Folic acid 800 mg; Antioxidant 100,000 mg; Fe 100,000 mg; Cu 16,000 mg; I 2,400 mg; Zn 100,000 mg; Mn 140,000 mg; Se 400 mg.

${ }^{* *}$ Inert (Kaolin) - Industrial Val was added to replace inert ingredient. 
recomendadas por Rostagno et al(10), con excepción de los niveles de Val digestible (Cuadro 1). Entre 15 y 42 días de edad, se mantuvieron las mismas relaciones Val:Lys dig según lo proporcionado de 1 a 14 días de edad; sin embargo, los niveles de la dieta se modificaron para satisfacer las necesidades nutricionales para aves de rendimiento promedio durante las fases de crecimiento y finalización(10).

Las aves se alojaron en un cobertizo regular de $30 \times 8 \mathrm{~m}$, dividido en corrales de $5.2 \mathrm{~m}^{2}$, cubierto por un techo de cemento, pisos de concreto y paredes laterales de ladrillo de $0.4 \mathrm{~m}$ de altura, complementado con malla de alambre hasta el techo, con cortinas de rafia movible. La temperatura se mantuvo a $32{ }^{\circ} \mathrm{C}$ en el inicio y se redujo gradualmente para asegurar comodidad utilizando un calentador termostático, ventiladores y nebulizadores. El programa de iluminación durante todo el estudio consistió en $23 \mathrm{~h}$ de luz y $1 \mathrm{~h}$ de oscuridad. El alimento se proporcionó libremente en forma de pasta y las aves tuvieron libre acceso al agua.

Se pesaron las aves y el alimento a los 7, 14 y 42 días de edad, para evaluar el desempeño (consumo de alimento, aumento de peso y conversión alimenticia). La mortalidad de las aves se registró diariamente, junto con la causa probable según lo determinado por necropsia, momento en el cual se pesaron para ajustar el consumo de alimento y conversión alimenticia.

A los 14 días de edad, se realizó un análisis de emplume en cinco aves elegidas al azar por repetición, y se evaluó por dos métodos. El primer método siguiendo los criterios adoptados por Edenset a(11), y consistió en evaluaciones visuales asignando una puntuación de 0 a 5 basada en niveles de densidad y etapa de desarrollo de las plumas en las siguientes regiones: espalda (dorso-pélvica), pecho (pectoral y esternal), piernas (fémur) y alas (humeral y cubierta superior marginal del patagio). Las puntuaciones correspondieron a 0 muy pobre; 1 pobre; 2 regular; 3 bueno; 4 muy bueno; 5 excelente. wire extending up to the ceiling, featuring movable raffia curtains. Temperature was maintained at $32{ }^{\circ} \mathrm{C}$ at placement and was gradually reduced to ensure comfort using a thermostatically controlled heater, fans, and foggers. The lighting program throughout the study consisted of $23 \mathrm{~h}$ of light and $1 \mathrm{~h}$ of dark. Feed was provided in mash form and birds had free access to feed and water.

The birds and feeds were weighed at 7,14 and $42 \mathrm{~d}$ of age, to evaluate performance (feed intake, weight gain and feed conversion). Bird mortality was recorded daily, along with the probable cause as determined by necropsy, at which time they were weighed to adjust feed intake and feed conversion.

At $14 \mathrm{~d}$ of age, a feathering analysis was conducted in five randomly chosen birds per replicate. Feathering was evaluated by two methods. The first method followed the criteria adopted by Edens et a(11) and consisted of visual evaluations assigning a score from 0 to 5 based on feathering density and the developmental stage of the feathers in the following regions: back (dorsopelvic), breast (pectoral and sternal), legs (femoral) and wings (umeral and superior marginal covering of the propatagium). Scores ranged from 0 to 5 , as follows: $0=$ Very poor; $1=$ Poor; $2=$ Regular; $3=$ Good; $4=$ Very good; $5=$ Excellent.

In the second method, feather development was evaluated according to Wylie et a(12). For this analysis, the dorsopelvic region (back) was divided into two parts, specifically, cranial and caudal. In the central portion of the caudal region, the length of 15 random feathers was measured for each bird, and the mean was used for statistical analysis. Similarly, the length of five feathers from the proximal portion of the femoral region (thigh) was measured for each selected bird.

At $14 \mathrm{~d}$ of age, 1 bird per experimental unit was sacrificed by electrical stunning followed by exsanguination. Following slaughter, the 
En el segundo método, el desarrollo de la pluma se evaluó según Wylie et a(12). Para este análisis, la región dorso pélvica se dividió en dos partes, específicamente, craneal y caudal. En la porción central de la región caudal, se midió la longitud de las plumas al azar (15 por cada ave), y la media se utilizó para el análisis estadístico. Asimismo, se midió la longitud de cinco plumas de la porción proximal de la región femoral (muslo) por cada ave seleccionada.

A los 14 días de edad, 1 ave por unidad experimental se sacrificó por aturdimiento eléctrico seguido por desangramiento. Tras la matanza, el músculo flexor hallucis longus del muslo izquierdo fue extraído, recortado y reducido a fragmentos de aproximadamente 1 x $2.5 \mathrm{~cm}$ de tamaño. Las muestras fueron etiquetadas, congeladas y almacenadas en nitrógeno líquido. Más tarde, las muestras se transfirieron y almacenaron en un congelador a $-80{ }^{\circ} \mathrm{C}$ durante $72 \mathrm{~h}$ antes del procesamiento.

Las muestras se transfirieron con una hora de anticipación del proceso, a un micrótomo criostático TISSUE TEK II a $-23^{\circ} \mathrm{C}$. Para obtener las secciones, cada muestra se fijó en un soporte metálico, utilizando tejido Tek OCT (temperatura óptima de cristal). Se realizaron un total de cinco secciones, de $8 \mu \mathrm{m}$ de espesor y con sección transversal de la fibra, fijado con un portaobjetos de vidrio para histología y almacenado en un congelador a $-18{ }^{\circ} \mathrm{C}$.

Para medir el diámetro de la fibra muscular del músculo flexor a los 14 días de edad, las diapositivas se tiñeron con hematoxilina-eosina y se analizaron bajo un microscopio de luz conectado a una cámara digital. Las imágenes obtenidas se analizaron usando software para imágenes Motic. Un total de 10 imágenes del tejido muscular se capturaron por ave evaluada, con un aumento final equivalente a un lente de 10X. Todas las fibras en las 10 imágenes se midieron, utilizando el método de medición de diámetro de fibra más pequeña(6).

Para evaluar la frecuencia del tipo de fibra muscular, las diapositivas se sometieron a la flexor hallucis longus muscle of the left thigh was extracted, trimmed and reduced to fragments approximately $1 \times 2.5 \mathrm{~cm}$ in size. The samples were labeled, frozen and stored in liquid nitrogen. Later, the samples were transferred and stored in a freezer at $-80^{\circ} \mathrm{C}$ for $72 \mathrm{~h}$ prior to processing.

The samples were transferred 1 hour in advance of processing to a TISSUE TEK II microtome cryostat at $-23^{\circ} \mathrm{C}$. To obtain the sections, each sample was fixed in a metal holder, using Tissue Tek OCT (Optimal Crystal Temperature). A total of five sections were made, measuring $8 \mu \mathrm{m}$ thick and cross-sectional from the fiber, captured with a glass slide for histology, and stored in a freezer at $-18{ }^{\circ} \mathrm{C}$.

To measure the muscle fiber diameter of the flexor hallucis longus muscle at $14 \mathrm{~d}$ of age, the slides were stained with Hematoxylin-Eosin and analyzed under a light microscope attached to a digital camera. The obtained images were analyzed using Motic Images software. A total of 10 images of muscle tissue were captured per evaluated bird, with a final magnification equivalent to a 10X lens. All fibers in the 10 images were measured, using the smallest fiber diameter measurement method(6).

To evaluate the frequency of muscle fiber type, the slides were subjected to the Nicotinamide Adenine Dinucleotide Tetrazolium Reductase (NADHTR) histo-enzyme technique. The fibers were classified as slow-twitch oxidative (SO), fast-twitch oxidative-glycolytic (FOG) or fast twitch glycolytic (FG)(13). To determine fiber type, images of 10 microscopic fields were captured from each sample, with a final magnification equivalent to a $40 \mathrm{X}$ lens, using Motic image analysis software.

For carcass and parts yields of its respective sections, two 42-d-old birds were selected at random from each experimental unit and tagged, then fasted for $6 \mathrm{~h}$ and sacrificed by electrical stunning followed by exsanguination. The calculation of carcass yield considered the 
técnica de histo-enzima nicotinamida adenina dinucleótido de tetrazolio reductasa (NADHTR). Las fibras se clasificaron como contracción lenta oxidativa (LO), contracción rápida oxidativaglicolítica (ROG) o contracción rápida glicolítica (RG), descrita por Peter et al(13). Para determinar el tipo de fibra, se capturaron imágenes de 10 campos microscópicos de cada muestra, con un aumento final equivalente a un objetivo de 40X, utilizando el software de análisis de imagen Motic.

Para rendimiento en canal y de las piezas de sus respectivas secciones, dos aves de 42 días de edad se seleccionaron al azar de cada unidad experimental, se etiquetaron y después de un ayuno de $6 \mathrm{~h}$ se sacrificaron por aturdimiento eléctrico seguido por desangramiento. El cálculo del rendimiento de la canal considera el peso de la canal eviscerada, sin patas, cabeza y grasa abdominal, en relación con el peso vivo de las aves que se pesaron individualmente previo al sacrificio. El rendimiento de los cortes de la canal se determinó teniendo en cuenta el rendimiento de pechuga entera con piel y huesos, y las piernas (muslo y muslo con piel y huesos) calculado en relación con el peso de la canal eviscerada. Se quitó la grasa abdominal alrededor de la cloaca, bursa cloacal, molleja, proventrículo y músculos abdominales adyacentes; se pesó, calculada también en relación con el peso de la canal eviscerada.

Antes del análisis estadístico, se evaluaron datos de normalidad mediante la prueba de ShapiroWilk y de heterogeneidad mediante la prueba de Levene. Datos sobre rendimiento, diámetro y frecuencia de la fibra del músculo, rendimiento en canal y longitud de pluma se sometiron a análisis de varianza y regresión polinomial, utilizando el software estadístico SAS 9.2(14). Los datos de puntuación de emplume no mostraron una distribución normal y se analizaron utilizando la metodología del modelo lineal generalizado por distribución Gamma inversa mediante el procedimiento PROC GENMOD de SAS 9.2(14). weight of the eviscerated carcass, without the feet, head and abdominal fat, in relation to the live weight of the birds that were weighed individually prior to slaughter. The yield of carcass cuts was determined by considering the yield of whole breast with skin and bones, and legs (drumstick and thigh with bones and skin) calculated in relation to eviscerated carcass weight. Abdominal fat around the cloaca, cloacal bursa, gizzard, proventriculus and adjacent abdominal muscles was removed. Next, the fat was weighed and also calculated in relation to eviscerated carcass weight.

Data were assessed for normality using the Shapiro-Wilk test and for heterogeneity using Levene's test before analysis. Data on performance, diameter and frequency of muscle fiber, carcass yield and feather length were subjected to analysis of variance and polynomial regression, using SAS 9.2 statistics software(14). The feathering score data did not show a normal distribution and was analyzed using the generalized linear model methodology by inverse Gamma distribution via the PROC GENMOD procedure of SAS 9.2(14).

\section{RESULTS AND DISCUSSION}

The dig Val:Lys ratio in the diet did not influence $(P>0.05)$ bird performance (Table 2$)$. This implies that the $0.90 \%$ level of dig Val, corresponding to a dig Val:Lys ratio of $66 \%$, was sufficient to maximize the performance of male broilers aged 1 to $14 \mathrm{~d}$. Corzo et al(15) established a similar dig Val level of $0.91 \%$ for birds in the same phase. However, the Val:Lys ratio obtained in this study was lower than that recommended by others $(2,16)$ of $77 \%$ for broilers in the first $21 \mathrm{~d}$ of age.

Dozier III et a(17) found optimal feed conversion in chickens receiving diets containing a high Val:Lys ratio $(82 \%)$ when the dig Ile:Lys increased from 63 to $68 \%$. Likewise, other works $(18)$ found improved feed conversion in birds that received diets with combined Val and 


\section{RESULTADOS Y DISCUSION}

La relación Val:Lys dig no influyó en el rendimiento de las aves $(P>0.05)$ (Cuadro 2). Esto implica que el nivel de $0.90 \%$ de Val, correspondiente a una relación Val:Lys dig del $66 \%$, fue suficiente para maximizar el rendimiento de pollos machos de 1 a 14 días de edad. Corzo et al(15) establecieron un nivel similar de Val del $0.91 \%$ para las aves en la misma fase. Sin embargo, la proporción de Val:Lys dig obtenida en este estudio fue más baja que la recomendada por otros $(2,16)$ de $77 \%$ para pollos de engorda en los primeros 21 días de edad.

Dozier III et al(17) encontraron una óptima conversión alimenticia en pollos que recibieron dietas que contenían una proporción alta de Val:Lys dig (82\%) cuando la relación Ile:Lys aumentó de 63 a $68 \%$. Asimismo, otros investigadores(18) encontraron mejor conversión alimenticia en las aves que recibieron dietas con suplementos de Val y Ile combinados, pero no cuando estos aminoácidos se agregaron individualmente.

La falta de suplementación de Ile podría haber sido la razón por la que no se encontraron efectos positivos sobre el rendimiento con la mayor relación Val:Lys dig. Aunque Val es el cuarto aminoácido limitante para pollos de engorda en dietas a base de maíz y harina de soya $(18,19)$, combinar la suplementación de Val y Ile es necesario para optimizar el rendimiento de las aves, haciendo inútil la suplementación Val cuando la deficiencia de Ile empieza a prevalecer(18).

Hubo un efecto positivo lineal $(P<0.05)$ de Val:Lys dig en la longitud de la pluma de la espalda y en la puntuación de emplume del muslo y pecho (Cuadros 3 y 4). Val es esencial para el desarrollo de la pluma(20), y representa el $20 \%$ de las proteínas de la pluma(21). Corzo et a(22) no informaron de anormalidades en las plumas de las aves alimentadas con dietas deficientes en Val; sin embargo, observaron un menor número de aves con laceraciones en la
Cuadro 2. Rendimiento de pollos de engorda alimentados con diferentes relaciones porcentuales de Val:Lys digestible entre 1 y 14 días de edad

Table 2. Performance of broilers fed with different dig Val:Lys between 1 and $14 \mathrm{~d}$ of age

\begin{tabular}{lccc}
\hline $\begin{array}{l}\text { Dig Val: } \\
\text { Lys }(\%)\end{array}$ & $\begin{array}{c}\text { Weight } \\
\text { gain }(\mathrm{g})\end{array}$ & $\begin{array}{c}\text { Feed } \\
\text { intake }(\mathrm{g})\end{array}$ & $\begin{array}{c}\text { Feed } \\
\text { conversion }(\mathrm{g} / \mathrm{g})\end{array}$ \\
\hline 66 & 341.97 & 457.66 & 1.339 \\
71 & 331.60 & 445.08 & 1.345 \\
76 & 339.67 & 451.01 & 1.329 \\
81 & 350.11 & 467.26 & 1.335 \\
86 & 327.93 & 447.63 & 1.365 \\
CV, \% & 5.20 & 3.46 & 3.61 \\
Regression & $\mathrm{ns}$ & $\mathrm{ns}$ & $\mathrm{ns}$ \\
\hline
\end{tabular}

$\mathrm{cV}=$ Coefficient of variation; $\mathrm{ns}=$ non-significant $(P>0.05)$.

Ile supplementation, but not when these amino acids were added individually.

The lack of Ile supplementation might have been the reason why positive effects on bird performance were not found with the increased dig Val:Lys ratio. Although Val is the fourth limiting amino acid for broilers under corn- and soybean meal-based diets $(18,19)$, combined Val and Ile supplementation is necessary to optimize bird performance, making Val supplementation useless when Ile deficiency begins to prevail(18).

There was a positive linear effect $(P<0.05)$ of dig Val:Lys ratio on feather length on the back and on the feathering score of the thigh and breast (Table 3 and 4). Val is essential for feather development(20), accounting for $20 \%$ of feather proteins(21). Corzo et al(22) did not report abnormalities in the feathers of birds fed with Val-deficient diets; however, they did observe a lower number of birds with lacerations on the back and legs with Val supplementation.

The first $21 \mathrm{~d}$ of life are important for the development of feather follicles and for feathering, and the quality of the early diet affects the number of lacerated carcasses at the slaughter line(23). Adequate Val levels during the early stage are 
espalda y las piernas con la suplementación de Val.

Los primeros 21 días de vida son importantes para el desarrollo de los folículos de la pluma y el emplume, y la calidad de la dieta temprana afecta el número de cuerpos lacerados en la línea de matanza(23). Niveles adecuados de Val durante la primera etapa son cruciales para el emplume, dado que las dietas deficientes en Val reducen los niveles de proteína en las plumas y comprometen la concentración de todos los aminoácidos que componen la proteína del plumaje(24).

Aves alimentadas con dietas deficientes en Val, combinadas con altos niveles de Leu mostraron pobre emplume $(9,24)$. Alta ingesta de Leu estimula deshidrogenasa de $\alpha$-cetoácidos de cadena ramificada, una enzima clave implicada en la degradación de los tres $\operatorname{AACR}(25)$, por lo tanto, la mayor inclusión de Leu conduce a una mayor oxidación de Val, reduciendo las concentraciones séricas y reduciendo su disponibilidad para la síntesis de proteínas en las plumas. La harina de soya incluye una gran cantidad de Leu; cuando este ingrediente se utiliza en la formulación de raciones, el contenido dietético de Leu en la alimentación generalmente supera los requerimientos nutricionales de pollos de engorda(26). La suplementación de $\mathrm{Val}$ en la dieta probablemente minimizó el efecto antagonista de Leu, resultando en mayor emplume de las aves.

Se definieron tres tipos de fibras básicas en aves(6): rojo (LO), blanco (RG) e intermediario (ROG). Ashmoreet $a\left({ }^{4}\right)$ sugieren que el aumento de la musculatura del animal (crecimiento) se acompaña de cambios en la proporción de fibras del músculo, un proceso que involucra una mayor conversión de fibras intermediarias en fibras blancas. Aunque Val es un aminoácido esencial para el crecimiento y mantenimiento del tejido, la frecuencia de las fibras en el músculo flexor hallucis longus no estuvo influenciada $(P>0.05)$ por los tratamientos a crucial for feathering, given that Val-deficient diets reduce protein levels in the feathers and compromise the concentration of all amino acids that make up the protein in plumes(24).

Birds fed Val-deficient diets combined with high levels of Leu showed poor feathering $(9,24)$. High

Cuadro 3. Emplume $(\mathrm{mm})$ en el muslo y la parte posterior del pollo de engorda alimentados con diferentes relaciones porcentuales de Val:Lys digestible de 1 a 14 días de edad

Table 3. Length of feathers $(\mathrm{mm})$ on the thigh and back of broilers fed different dig Val:Lys ratios from 1 to $14 \mathrm{~d}$ of age

\begin{tabular}{ccc}
\hline Dig Val:Lys (\%) & Thigh & Back \\
\hline 66 & 17.9 & 6.5 \\
71 & 18.5 & 8.5 \\
76 & 18.3 & 8.5 \\
81 & 18.9 & 8.6 \\
86 & 19.0 & 9.2 \\
CV, \% & 7.43 & 24.52 \\
Regression & ns & linear $^{1}$ \\
\hline
\end{tabular}

ns $=$ non-significant $(P>0.05)$.

${ }^{1} \mathrm{Y}=-0.1+0.11 \mathrm{x} ; \mathrm{R}^{2}=0.72$.

Cuadro 4. Puntuación de emplume de pollos de engorda alimentados con diferentes relaciones porcentuales de Val:Lys digestibles de 1 a 14 días de edad ${ }^{1}$

Table 4. Feathering score of broilers fed different dig Val:Lys ratios from 1 to $14 \mathrm{~d}$ of age ${ }^{1}$

\begin{tabular}{ccccc}
\hline Dig Val:Lys (\%) & Back & Wing & Thigh & Breast \\
\hline 66 & 2.53 & 2.40 & 2.60 & 2.93 \\
71 & 2.77 & 2.47 & 2.80 & 3.10 \\
76 & 2.36 & 2.20 & 2.32 & 2.90 \\
81 & 2.67 & 2.53 & 3.33 & 3.57 \\
86 & 3.07 & 3.00 & 3.17 & 3.67 \\
CV, \% & 21.55 & 23.30 & 17.54 & 13.73 \\
Regression & ns & ns & linear $^{2}$ & linear $^{3}$ \\
\hline
\end{tabular}

ns $=$ non-significant $(P>0.05)$.

${ }^{1}$ Score from 0 to $5,1=$ low feathering; $5=$ high feathering.

${ }^{2} Y=0.305+0.033 x ; R^{2}=0.41$.

${ }^{3} Y=0.27+0.039 x ; R^{2}=0.73$. 
los 14 días de edad (Cuadro 5). En contraste con Lys, Val no tiene efectos pronunciados en la composición corporal(7) y, por tanto, no puede influir en el perfil de las fibras musculares.

Sin embargo, la relación Val:Lys dig afectó el tamaño de la fibra $(P<0.05)$, ya que hubo un efecto cuadrático de su proporción en el diámetro de las fibras en el músculo flexor hallucis longus, con una relación Val:Lys dig estimada de 76 \%. Por lo tanto, Val podría interferir en el crecimiento del tejido muscular, aumentado el tamaño de las fibras músculoesqueléticas sin conducir cambios en su perfil. Basada en la relación Val:Lys dig necesaria para maximizar el crecimiento de las fibras musculares (76\%), esta relación parece ser mayor que el requisito necesario para un óptimo desempeño (66\%).

Las aves se criaron hasta los 42 días de edad manteniendo la misma relación de Val:Lys dig según lo proveído de 1 a 14 días de edad. Cuando se consideró el total del periodo de cría (1 a 42 días), no se detectó ninguna influencia $(P>0.05)$ de la relación de Val:Lys dig sobre el desempeño, rendimiento de la canal
Leu intake stimulates dehydrogenase of branched-chain $\alpha$-ketoacids, a key enzyme involved in the degradation of the three $B C A A(25)$. Therefore, the higher inclusion of Leu leads to greater Val oxidation, reducing serum concentrations and thereby reducing their availability roved feathering in birds.

Three types of basic fibers were defined in birds (6): red (SO), white (FG) and intermediary (FOG). Ashmore et al(4) suggested that the increase in animal musculature (growth) is accompanied by changes in the ratio of muscle fibers, a process that involves greater conversion of intermediary fibers into white fibers. Although Val is an essential amino acid for tissue maintenance and growth, the frequency of fibers in the flexor hallucis longus muscle was not influenced $(P>0.05)$ by the treatments at $14 \mathrm{~d}$ of age (Table 5). In contrast to Lys, Val does not have pronounced effects on body composition(7) and, therefore, may not influence the profile of muscle fibers.

Nevertheless, the dig Val:Lys ratio did affect fiber size $(P<0.05)$, as there was a quadratic effect of the dig Val:Lys ratio on the diameter

Cuadro 5. Frecuencia y diámetro de las fibras musculares en el músculo flexor hallucis longus de pollos de engorda alimentados con diferentes relaciones porcentuales de Val:Lys digestible de 1 a 14 días de edad

Table 5. Frequency and diameter of muscle fibers in the flexor hallucis longus muscle of broilers fed different dig Val:Lys ratios from 1 to $14 \mathrm{~d}$ of age

\begin{tabular}{ccccc}
\hline & \multicolumn{3}{c}{ Frequency (\%) } & \\
\cline { 2 - 4 } Dig Val:Lys (\%) & SO & FOG & FG & Diameter $(\mu \mathrm{m})$ \\
\hline 66 & 31.05 & 24.97 & 43.98 & 26.17 \\
71 & 28.55 & 22.46 & 48.98 & 24.64 \\
76 & 31.59 & 20.12 & 48.29 & 29.04 \\
81 & 31.01 & 22.82 & 46.16 & 28.21 \\
86 & 25.89 & 26.98 & 47.13 & 22.90 \\
CV, \% & 13.78 & 24.13 & 13.77 & 11.67 \\
Regression & ns & ns & ns & Quadratic $^{1}$ \\
\hline
\end{tabular}

$\mathrm{SO}=$ Slow oxidative; $\mathrm{FOG}=$ Fast oxidative glycolytic; $\mathrm{FG}=$ Fast glycolytic .

ns $=$ non-significant $(P>0.05)$.

${ }^{1} Y=-178.5+5.495 x-0.036 x^{2} . R^{2}=0.50 ;$ maximum point of $76 \%$ dig Val:Lys. 
o grasa abdominal (Cuadro 6). Sin embargo, mejoró el rendimiento de la pierna $(P<0.05)$ linealmente conforme la relación Val:Lys dig aumentó en la dieta. Un resultado similar fue descrito por otros(15), quienes encontraron un efecto positivo sobre el rendimiento de la pierna al incrementarse los niveles dietéticos de Val.

La concentración de los AACR (Val, Ile y Leu) varía según el tipo de fibra muscular presente en el tejido, siendo 20 a $30 \%$ mayor en fibras (rojo) de contracción lenta en comparación con las fibras de contracción rápida (blancas)(27). La mayor concentración de Val en fibras rojas podría explicar el mayor rendimiento de pierna encontrado a los 42 días, ya que hay una mayor proporción de ese tipo de fibra en los músculos de la pierna en relación con otros tejidos musculares(28). Esta musculatura tiene una función postural, siendo utilizada para mantener a las aves paradas, y por lo tanto exige la contracción continua durante un período prolongado -para el que las fibras rojas son específicamente adecuadas- al fatigarse menos (lenta oxidativo)(4).

La relación Val:Lys dig no influyó en el rendimiento de pechuga a los 42 días de edad of the fibers in the flexor hallucis longus muscle, with an estimated dig Val:Lys ratio of $76 \%$. Therefore, Val could interfere in muscle tissue growth, increasing the size of muscle-skeletal fibers without leading to changes in their profile. Based on the dig Val:Lys ratio required to maximize the growth of muscle fibers (76 \%) seems to be greater than the needed requirement for optimum performance (66\%).

The birds were reared up to $42 \mathrm{~d}$ of age while maintaining the same dig Val:Lys ratio as supplied from 1 to $14 \mathrm{~d}$ of age. When the total rearing period ( 1 to $42 \mathrm{~d}$ ) was considered, there was no influence $(P>0.05)$ of the dig Val:Lys ratio on performance, carcass yield or abdominal fat (Table 6). However, leg yield improved $(P<0.05)$ linearly as the dig Val:Lys ratio increased in the diet. A similar result was described by others(15), who found a positive effect on leg yield of the increase in dietary Val levels.

The concentration of BCAA (Val, Ile and Leu) varies according to the type of muscle fiber present in the tissue, being 20 to $30 \%$ higher in slow-twitch (red) fibers compared to fast-twitch (white) fibers(27). The higher concentration of

Cuadro 6. Rendimiento en canal, rendimiento, recortes y grasa abdominal (AF) de pollos de engorda alimentados con diferentes relaciones porcentuales de Val:Lys digestible de 1 a 14 días de edad 1

Table 6. Performance and carcass yield, cuts and abdominal fat (AF) of broilers fed different dig Val:Lys ratios from 1 to $14 \mathrm{~d}$ of age 1

\begin{tabular}{ccccccc}
\hline Dig Val:Lys (\%) & Weight gain $(\mathrm{g})$ & Feed conversion $(\mathrm{g} / \mathrm{g})$ & Carcass $(\%)$ & Breast $(\%)$ & Leg $(\%)$ & AF $(\%)$ \\
\hline 66 & 2473.12 & 1.781 & 74.88 & 34.73 & 29.59 & 2.88 \\
71 & 2466.97 & 1.742 & 74.88 & 35.74 & 30.84 & 2.92 \\
76 & 2502.66 & 1.766 & 74.90 & 34.62 & 30.14 & 2.87 \\
81 & 2561.82 & 1.730 & 74.97 & 36.15 & 30.77 & 2.86 \\
86 & 2455.85 & 1.764 & 74.86 & 35.05 & 32.62 & 2.70 \\
CV, $\%$ & 2.88 & 1.66 & 0.79 & 4.05 & 7.81 & 14.66 \\
Regression & $\mathrm{ns}$ & $\mathrm{ns}$ & $\mathrm{ns}$ & $\mathrm{ns}$ & Linear $^{2}$ & $\mathrm{~ns}$ \\
\hline
\end{tabular}

1 Birds that received conventional feed during the growth and final stages, maintaining the same dig Val:Lys rations as supplied from 1 to $14 \mathrm{~d}$ of age.

ns $=$ non-significant $(P>0.05)$.

$2 Y=21.68+0.119 x ; R^{2}=0.70$. 
$(P>0.05)$. Es sabido que el músculo de la pechuga de pollo se compone predominantemente de fibras blancas(29); por lo tanto, Val no podría influenciar directamente la hipertrofia en ese tipo de fibra muscular. A diferencia de la Val, Lys puede estimular el crecimiento de las fibras blancas del músculo(7), que es por lo que la suplementación de Lys en pollos usualmente resulta con un rendimiento superior de pechuga $(23,30)$.

\section{CONCLUSIONES E IMPLICACIONES}

El nivel de $0.90 \%$ de valina digestible, correspondiente a una relación porcentual de valina:lisina del $66 \%$, es suficiente para maximizar el rendimiento de pollos de engorda en el periodo de 1 a 14 días; sin embargo, una relación mayor (76 \%) es necesaria para maximizar el crecimiento de las fibras musculares. Valina demostró ser un aminoácido primordial para el desarrollo de la pluma durante las primeras etapas de vida de pollos de engorda.

\section{AGRADECIMIENTOS}

Becas del Consejo Nacional de Desarrollo Científico y Tecnológico (CNPq), Brasil.

\section{LITERATURA CITADA}

1. Vieira SL, Lima IL. Live performance, water intake and excreta characteristics of broilers fed all vegetable diets based on corn and soybean meal. Poult Sci 2005;4(6):365368

2. Rostagno HS, Albino LFT, Donzele JL, Gomes PC, De Oliveira RF, Lopes DC, et al. Tabelas Brasileiras para Aves e Suínos. Composição de Alimentos e Exigências Nutricionais. 3ed. Viçosa: UFV; 2011.

3. Tuttle $\mathrm{WL}$, Balloun SL. Leucine, isoleucine and valine interactions in turkey poults. Poult Sci 1976;55:1737-1743.

4. Ashmore CR, Tompkins G, Doerr L. Postnatal development of muscle fiber types in domestic animals. J Anim Sci 1972;34(1):37-41.

5. Shimomura $Y$, Yamamoto $Y$, Bajotto GS, Sato J, Murakami $\mathrm{T}$, Shimomura N, et al. Nutraceutical effects of branched-
Val in red fibers might explain the greater leg yield found at $42 \mathrm{~d}$, as there is a higher ratio of that type of fiber in leg muscles in relation to other muscle tissues(28). This musculature has a postural function, being used to keep the bird standing, and consequently demands continuous contraction for a prolonged period -for which red fibers are specifically suited-, as they are less easily fatigued (slow oxidative)(4).

The dig Val:Lys ratio did not influence the breast yield at $42 \mathrm{~d}(P>0.05)$. It is known that the breast muscle of chicken is composed predominantly of white fibers(29); therefore, Val could not directly influence hypertrophy in that type of muscle fiber. Unlike Val, Lys can stimulate the growth of white muscle fibers(7), which is why Lys supplementation usually results in chickens with a higher breast yield $(23,30)$.

\section{CONCLUSIONS AND IMPLICATIONS}

The level of $0.90 \%$ digestible valine, corresponding to a valine:lysine ratio of $66 \%$, is sufficient to maximize the performance of broilers at 1 to $14 \mathrm{~d}$; however, a higher ratio (76\%) is necessary to maximize the growth of muscle fibers. Valine proved to be a primordial amino acid for feather development during the early life stages of broilers.

\section{ACKNOWLEDGMENTS}

Grants from National Council of Technological and Scientific Development (CNPq), Brazil.

End of english version

chain amino acids on skeletal muscle. J Nutr 2006;136:529532.

6. Dubowitz V, Brooke MH. Muscle biopsy: a modern approach. London: Saunders; 1973.

7. Leclercq B. Specific effects of lysine on broiler production: comparison with threonine and valine. Poult Sci 1998;77:118123. 


\section{RELACIÓN VALINA: LISINA DIGESTIBLE EN LA DIETA DE POLLOS DE ENGORDA}

8. Leeson S, Summers JD. Scott's Nutrition of the chicken. 4th ed. Guelph, Ontario Canada: University Books; 2001.

9. D'Mello JPF, Lewis D. Amino acid interactions in chick nutrition. 2. Interrelationships between leucine, isoleucine, and valine. Poult Sci 1970;11:313-323.

10. Rostagno HS, Albino LFT, Donzele JL, Gomes PC, Oliveira RF, Lopes DC, Ferreira AS, Barreto SLT. Tabelas Brasileiras para Aves e Suínos: Composição de Alimentos e Exigências Nutricionais. 2nd ed. UFV; 2005.

11. Edens F, Parkhurst CR, Havenstein GB. Housing and selenium influences on feathering in broilers. J Appl Poultry Res 2001; 10:128-134.

12. Wylie LM, Robertson GW, Macleod MG. Effects of ambient temperature and restricted feeding on growth of feathers in growing turkeys. Brit Poult Sci 2001;42:449-455.

13. Peter JB, Barnard RJ, Edgerton VR, Gillespie CA, Stempel KE. Metabolic profiles of three fiber types of skeletal muscle in Guinea pig and rabbits. Biochem 1972;11:2627-2633.

14. SAS Institute. SAS Proprietary Software, Release 9.2. SAS Inst. Inc., Cary, NC; 2009.

15. Corzo A, Dozier III WA, Kidd MT. Valine nutrient recommendations for Ross $\times$ Ross 308 broilers. Poult Sci 2008; 87:335-338.

16. Baker $\mathrm{DH}$, Batal $\mathrm{AB}$, Parr TM, Augspurger NR, Parsons CM. Ideal ratio (relative to lysine) of tryptophan, threonine, isoleucine and valine for chicks during the second and third weeks posthatch. Poult Sci 2002;81:485-494.

17. Eits RM, Kwakkel RP, Verstegen MWA, Emmans GC. Responses of broiler chickens to dietary protein: effects of early life protein nutrition on later responses. Poult Sci 2003;44:398-409.

18. Dozier III WA, Tillman PB, Usry J. Interactive effects of digestible valine and isoleucine-to-lysine ratios provided to male broilers from 4 to 6 weeks of age. J Appl Poultry Res 2012;21:838-848.

19. Corzo A, Loar II RE, Kidd MT. Limitations of dietary isoleucine and valine in broiler chick diets. Poult Sci 2009;88:19341938.
20. Corzo A, Kidd M, Dozier III WA, Vieira SL. Marginality and needs of dietary valine for broilers fed certain all-vegetable diets. J Appl Poultry Res 2007;16:546-554.

21. Gregg K, Rogers GE. Feather keratin: composition, structure and biogenesis. In: Biology of the integument, Springer Verlag; 1986.

22. Scott ML, Nesheim MC, Young RG. Nutrition of the chicken. 3rd ed. Ithaca: ML Scott and Associates; 1982.

23. Corzo A, Moran Jr ET, Hoehler D. Valine needs of male broilers from 42 to 56 days of age. Poult Sci 2004;83:946951.

24. Moran ET, Bilgili Jr SF. Processing losses, carcass quality and meat yield of broiler chickens as influenced by dietary lysine. Poult Sci 1990;69:702-710.

25. Farran MT, Thomas OP. Valine deficiency. 1. The Effect of feeding a valine-deficient diet during the starter period on performance and feather structure of male broiler chicks. Poult Sci 1992;71:1879-1884.

26. Harris RA, Kobayashi R, Murakami T, Shimomura Y. Regulation of branched-chain á-keto acid dehydrogenase kinase expression in rat liver. J Nutr 2001;131:841-845.

27. Imanari $M$, Kadowaki M, Fujimura $S$. Regulation of tasteactive components of meat by dietary branched-chain amino acids; effects of branched-chain amino acid antagonism. Br Poult Sci 2008;49(3):299-307.

28. Rogero MM, Tirapegui J. Aspectos atuais sobre aminoácidos de cadeia ramificada e exercício físico. Rev Bras Cienc Farm 2008;44(4):563-575.

29. Barnard EA, Lyles JM, Pizzey JA. Fibre types in chicken skeletal muscles and their changes in muscular dystrophy. J Physiol 1982;331:333-354.

30. Roy BC, Oshima I, Miyachi H, Shiba N, Nishimura S, Tabata $\mathrm{S}$, Iwamoto $\mathrm{H}$. Effects of nutritional level on muscle development, histochemical properties of myofibre and collagen architecture in the pectoralis muscle of male broilers. Brit Poult Sci 2006;47:433-442.

31. Berri C, Besnard J, Relandeau C. Increasing dietary lysine increases final $\mathrm{pH}$ and decreases drip loss of broiler breast meat. Poult Sci 2008;87(3):480-484. 
